\title{
УПРАВЛІНСЬКА ЗВІТНІСТЬ ПІДПРИЕМСТВА: ІНФОРМАЦІЙНЕ ЗНАЧЕННЯ Й ОПТИМАЛЬНА СТРУКТУРА
}

\section{MANAGEMENT REPORTING OF THE ENTERPRISE: INFORMATION SIGNIFICANCE AND OPTIMAL STRUCTURE}

\author{
Поліщук Олена Тимофіївна \\ кандидат економічних наук, доцент, \\ Донецький національний університет імені Василя Стуса \\ ORCID: https://orcid.org/0000-0002-2903-1885 \\ Шимко Наталія Олександрівна \\ магістрант, \\ Донецький національний університет імені Василя Стуса \\ ORCID: https://orcid.org/0000-0002-6335-1241
}

\author{
Polishchuk Olena, Shymko Natalia \\ Vasyl' Stus Donetsk National University
}

Статтю присвячено дослідженню ролі управлінської звітності для потреб менеджменту підприємства та обґрунтуванню її належного складу, що сприяло б забезпеченню апарату управління релевантною інформацією, орієнтованою на впровадження дієвих керівних рішень. Аргументовано доцільність фрормування управлінської звітності як головного джерела обліково-аналітичних даних для керівництва. Узагальнено різні підходи науковців та запропоновано три компоненти та структуру управлінської звітності: звітність про фрінансове становище та результати діяльності підприємства, за ключовими показниками діяльності, про виконання бюджетів, конкретизовано їх оптимальний зміст. Обґрунтовано важливість та необхідність фрормування управлінських звітів про ліквідність та платоспроможність підприємства, рентабельність, потенційність банкрутства. Розроблено форми звітів та запропоновано до використання.

Ключові слова: управлінська звітність, менеджмент, інформаційне забезпечення, структура управлінської звітності, есрективність господарювання.

Статья посвящена исследованию роли управленческой отчетности для нужд менеджмента предприятия и обоснованию ее надлежащего состава, что способствовало бы обеспечению аппарата управления релевантной информацией, ориентированной на внедрение действенных решений. Аргументирована целесообразность фрормирования управленческой отчетности как главного источника учетно-аналитических данных для руководства. Обобщены различные подходы ученых и предложены три компонента и структура управленческой отчетности: отчетность о фринансовом положении и результатах деятельности предприятия, по ключевым показателям деятельности, о выполнении бюджетов, конкретизировано их оптимальное содержание. Обоснованно необходимость формирования управленческих отчетов о ликвидности и платежеспособности предприятия, рентабельности, потенциальности банкротства. Разработаны фрормы отчетов и предложены к использованию.

Ключевые слова: управленческая отчетность, менеджмент, иноормационное обеспечение, структура управленческой отчетности, эфорективность хозяйствования.

The article is devoted to the study of the role of management reporting for the needs of enterprise management and substantiation of its proper composition. The purpose of the study is to substantiate the optimal structure of management reporting of the enterprise, focused on the information needs of managers to ensure the stability and efficiency of management. It is determined that the use of only financial statements is not enough to provide the management with relevant information focused on the implementation of effective management decisions. The expediency of forming management reporting as the main source of accounting and analytical data for management is argued. The basic requirements to the management reports providing value of the information presented in them for needs of management of the organization are stated. The views of scientists on the composition of management reporting of the enterprise are generalized. After all, it is known that the effectiveness of enterprise management is determined by the timeliness, feasibility and effectiveness of its decisions. Three components of management 
reporting are considered: reporting on the financial position and results of the enterprise, on key performance indicators, on the implementation of budgets, specifying their optimal content. It is management reporting as a carrier of key financial, production and other important data is designed to provide the management of the enterprise with relevant information. The importance and necessity of forming management reports on liquidity and solvency of the enterprise, profitability, potential of bankruptcy are substantiated. Examples of these reports have been developed and proposed for use. After all, each company, being interested in its own financial stability, must generate management reports that reflect the main indicators of its liquidity, solvency, profitability, probability of bankruptcy. Regarding the periodicity of these forms, it is considered optimal to generate reports both on the results of the reporting year and in the context of quarters. As a result, all this will help increase the investment attractiveness of the business, will contribute to the formation and publication of reports with analytical indicators.

Keywords: management reporting, management, information support, structure of management reporting, efficiency of management.

Постановка проблеми. Провадження підприємницької діяльності в динамічних ринкових умовах, нестабільності економічного стану держави, чутливості обраної галузі (підгалузі) економіки до непоправних змін дедалі сильніше змушує суб'єкта господарювання ретельно дбати про якість власної системи управління. Дієвість керівництва підприємством визначається своєчасністю, доцільністю та ефрективністю впроваджених ним рішень.

Для здійснення обґрунтованих ухвалень, націлених на досягнення організацією запланованих результатів, менеджмент гостро потребує відповідного інформаційного забезпечення. Саме управлінська звітність як носій ключових фрінансових, виробничих та інших важливих даних покликана забезпечити апарат управління підприємством релевантною інформацією. 3 огляду на цінність відомостей управлінської звітності для запитів керівництва актуальним залишається питання щодо ії̈ оптимальної структури.

Аналіз останніх досліджень і публікацій. Внаслідок актуалізації ролі облікової інформації в забезпеченні системи керівництва підприємством управлінська звітність досить часто виступає об'єктом різноманітних наукових досліджень. Окремі питання щодо іiі трактування та сутності, принципів підготовки, особливостей формування знаходили своє відображення в працях Куцика П.О. [1], Король С.Я. [2], Кузя В.І. [3], Гладій І.О. [4] та ін. Менше уваги в науковій літературі приділено структурі даної звітності та переліку розрахункових показників, важливих для відображення в управлінських звітах.

Виділення невирішених раніше частин загальної проблеми. Хоча управлінська звітність не регламентована та не обов'язкова для складання суб'єктами господарювання, але сьогодні, в умовах перманентності різного роду кризових явищ, відмічається іiї висока затребуваність та висуваються до неї все більші вимоги.
Незважаючи на науково-практичний доробок з даної тематики, разом 3 тим, не в повній мірі розкриті питання що стосуються фрормалізації форм та структури управлінської звітності, рівнів інорормаційних потреб та запитів, методики формування, що дозволяє стверджувати про наявність теоретично-практичних проблем за вказаними напрямками та необхідність в подальших дослідженнях.

Формування цілей стаття (постановка завдання). Мета дослідження полягає в обґрунтуванні оптимальної структури управлінської звітності підприємства, орієнтованої на інфрормаційні потреби менеджерів для забезпечення стабільності та ефективності господарювання. Досягнення поставленої мети реалізується виконанням наукових завдань: 3'ясувати значення управлінської звітності для менеджменту; встановити, які складові управлінської звітності $€$ оптимальними для фрормування з урахуванням потреб керівництва суб'єктом господарювання; запропонувати фрорми управлінських звітів, що не залежно від індивідуальних особливостей підприємств стануть в нагоді кожному суб'єкту підприємництва в процесі прийняття есрективних керівних рішень.

Виклад основного матеріалу дослідження. Законом «Про бухгалтерський облік та фрінансову звітність в Україні» на всіх юридичних осіб, створених відповідно до національного законодавства, покладено обов'язок складати та подавати фрінансову звітність [5]. Достатньо жорстка державна регламентація даної звітності, стандартизація ії фрорм, нормативно-правове регулювання переліку статей, можливих для відображення в окремих звітах, роблять фрінансову звітність головним інфрормаційним джерелом про підприємство здебільшого для зовнішніх зацікавлених осіб. В умовах закритості комерційних даних суб'єкта господарювання стейкхолдери, прагнучи проаналізувати основні показники його діяльності, оцінити перспективність та при- 
бутковість співпраці з ним, орієнтуються саме на дані фрінансової звітності, що перебувають у відкритому доступі. Однак, для апарату управління підприємства використання лише фрінансової звітності в процесі керівництва $\epsilon$ неможливим, оскільки вона виступає досить обмеженим інформаційним забезпеченням адміністрації.

Потреби внутрішніх користувачів звітності значно ширші: попередня оцінка майнового та фрінансового стану підприємства виступає передумовою для подальшого пошуку альтернативних і впровадження аргументованих управлінських рішень. На цій основі менеджери потребують вже не просто набору фрактичних даних за результатами діяльності організації у звітному періоді, а й аналітичних відомостей, які дадуть змогу порівняти ключові показники роботи впродовж конкретного часового проміжку, спостерігати їх динаміку, намітити тенденцію, дослідити вклад окремих підрозділів (сегментів діяльності) в загальні досягнення підприємства тощо. Головним джерелом обліково-аналітичних даних для керівництва $€$ управлінська звітність. Інфрормаційне забезпечення апарату управління повинне бути одночасно компактним і повним: окремі управлінські звіти мають містити оптимальний перелік показників, що дасть змогу на достатньому рівні проаналізувати та оцінити один конкретний або кілька тісно пов'язаних між собою напрямів роботи, характеристик підприємства, його діяльності. Натомість внаслідок інорормаційного перенасичення звітів значно знижується релевантність представлених у них даних для потреб менеджменту, а підприємство ризикує якістю та дієвістю власної системи управління.

Огляд наукової літератури [6, с. 33; 7, с. 38] дає підстави стверджувати, що управлінську

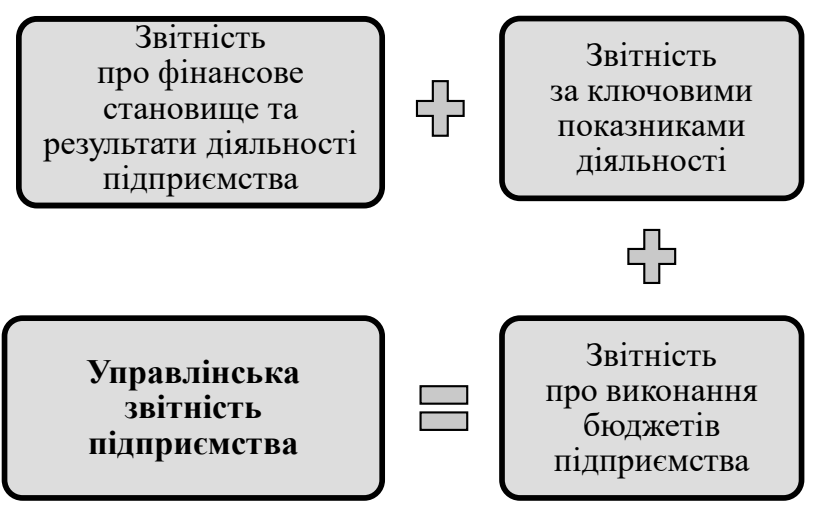

Рис. 1. Складові управлінської звітності підприємства

Джерело: складено авторами за [6-7] звітність підприємства доцільно формувати в розрізі трьох складових (рис. 1).

Управлінська звітність про фрінансове становище та результати діяльності суб'єкта господарювання зазвичай представлена управлінським балансом, звітом про фрінансові результати, звітом про рух грошових коштів. При цьому для їх фрормування може бути використано форми аналогічних фрінансових звітів, трансорормовані під конкретні потреби менеджерів із доповненням стовпцем, де буде зазначено абсолютні та відносні відхилення за показниками кожної представленої у звіті статті. Окрім цього, більшої аналітичності звітним фрормам надасть деталізація окремих статей, наприклад, у розрізі контрагентів, номенклатурних одиниць запасів тощо.

Звітність за ключовими показниками діяльності доцільно фрормувати як загалом по підприємству, так і окремо за центрами відповідальності. Це можуть бути звіти про виконання цільових показників, ефективність виробництва продукції, реалізації та ін. Формуючи комплексний звіт по підприємству, доречно розглянути можливість відображення в ньому відсоткового вираження вкладу кожного центру відповідальності в структурі прибутку організації за результатами звітного періоду. Звітність про виконання затверджених на підприємстві бюджетів має відображати заплановані та фрактично досягнуті показники, існуючі між ними відхилення, короткі пояснення щодо цього.

3 огляду на особливості численних організаційно-правових фрорм господарювання, специсріку різних видів діяльності, унікальність виробничих процесів управлінська звітність кожного підприємства є індивідуальною. Через це розробка стандартних фрорм звітності, що повністю забезпечували б інформаційні потреби служб управління різних організацій $є$ неможливою, окрема установа самостійно визначає та впроваджує необхідні для ефрективного керівництва фрорми звітів. Не зважаючи на індивідуальні риси підприємств, які визначають структуру їх управлінської звітності, всім суб'єктам підприємництва варто складати управлінські звіти, що відображатимуть показники його ліквідності, платоспроможності, рентабельності, а в умовах затяжних економічних криз і загострення конкуренції - додатково оцінювати можливість настання банкрутства. Вважаємо, прагнучи максимізувати есрективність власної діяльності, суб'єкт господарювання для потреб системи управління повинен фрормувати звіт 
Таблиця 1

Форма управлінського звіту про ліквідність та платоспроможність підприємства

\begin{tabular}{|c|c|c|c|c|c|c|}
\hline № & Показник & $\begin{array}{c}\text { Формула } \\
\text { розрахунку } \\
\text { (за даними } \\
\text { фінансової } \\
\text { звітності) }\end{array}$ & $\begin{array}{l}\text { Норматив. } \\
\text { значення }\end{array}$ & $\underset{1}{\text { Період }}$ & $\underset{2}{\text { Період }}$ & $\begin{array}{c}\text { Абсолютне } \\
\text { відхилення/ } \\
\text { Відносне } \\
\text { відхилення }\end{array}$ \\
\hline 1 & Робочий капітал & Ф.1 p.1195-p.1695 & $>30 \% \mathrm{OA}$ & & & \\
\hline 2 & $\begin{array}{l}\text { Еорективність } \\
\text { заборгованості }\end{array}$ & $\begin{array}{l}\text { Ф.1 p.1695-(p.1125+ } \\
+\cdots+\text { p.1165) }\end{array}$ & у динам. & & & \\
\hline 3 & $\begin{array}{l}\text { Коефріцієнт поточної } \\
\text { ліквідності }\end{array}$ & 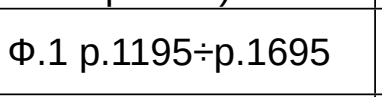 & $1-3$ & & & \\
\hline 4 & $\begin{array}{l}\text { Коефріцієнт швидкої } \\
\text { ліквідності }\end{array}$ & 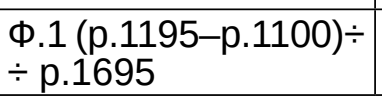 & $0,5-1$ & & & \\
\hline 5 & \begin{tabular}{|l|} 
Коесріцієнт \\
абсолютної \\
ліквідності \\
\end{tabular} & 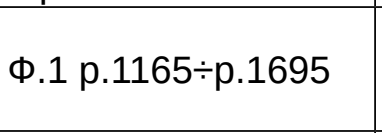 & $0,2-0,35$ & & & \\
\hline 6 & $\begin{array}{l}\text { Маневреність } \\
\text { робочого капіталу }\end{array}$ & $\begin{array}{l}\text { Ф.1 (p.1165+p.1160) } \div \\
\div(\text { p.1195-p.1695) }\end{array}$ & $>0$ & & & \\
\hline 7 & $\begin{array}{l}\text { Коефріцієнт } \\
\text { захищеного періоду }\end{array}$ & $\begin{array}{l}\text { Ф.1 p.1195 } \div(\Phi .2 \\
\text { p. } 2050+\text { p. } 2130+ \\
\text { p. } 2150+\text { p. } 2180) \div 360\end{array}$ & у динам. & & & \\
\hline 8 & $\begin{array}{l}\text { Коесріцієнт } \\
\text { забезпеченості } \\
\text { реалізації робочим } \\
\text { капіталом }\end{array}$ & $\begin{array}{l}\text { Ф.1 (p.1195-p.1695) } \div \\
\div \Phi .2 \text { p.2000 }\end{array}$ & у динам. & & & \\
\hline 9 & $\begin{array}{l}\text { Коефріцієнт } \\
\text { довгострок. } \\
\text { фрінансового } \\
\text { забезпечення } 1\end{array}$ & 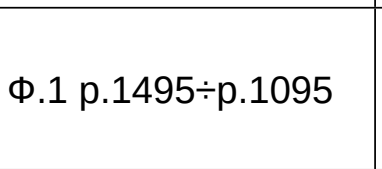 & $>0,5-0,7$ & & & \\
\hline 10 & $\begin{array}{l}\text { Коефріцієнт } \\
\text { довгострок. } \\
\text { фрінансового } \\
\text { забезпечення } 2\end{array}$ & $\begin{array}{l}\text { Ф.1 (p.1495+p.1595) } \div \\
\div \text { p.1095 }\end{array}$ & $>1$ & & & \\
\hline
\end{tabular}

Джерело: складено авторами за [8]

про ліквідність та платоспроможність, звіт про рентабельність, звіт про потенційність банкрутства. На нашу думку, складати звіт про ліквідність та платоспроможність підприємства варто за прикладом таблиці 1.

Обґрунтовуючи важливість впровадження даного звіту для організації, слід зазначити, що на основі його даних керівництво контролюватиме:

- здатність установи своєчасно розрахуватися за її короткостроковими зобов'язаннями;

- частину поточних зобов'язань підприємства, яку можливо погасити в терміновому порядку;

- величину оборотних коштів, що припадає на кожну гривню поточних зобов'язань;

- обсяг поточних зобов'язань, який можна покрити за рахунок надходжень від подальшої діяльності;

- частку абсолютно ліквідних активів у робочому капіталі, яка забезпечує свободу фрінансового маневру;
- час, протягом якого установа може вести поточну операційну діяльність за рахунок своїх ліквідних активів без залучення додаткових джерел фрінансування;

- показники дотримання фрінансової рівноваги підприємства в коротко та довгостроковому періодах [8]. Окрім цього, необхідно моніторити відхилення розрахункових показників від їх нормативних значень, оскільки значні розбіжності між ними $є$ свідченням неефективного управління оборотними активами підприємства. Оцінюючи стан підприємства на предмет його ліквідності та платоспроможності для потреб дієвого керівництва, доцільним $€$ формування зазначеного звіту в комплексі з аналізом змін у складі ресурсів суб'єкта господарювання та джерел їх утворення, розрахунком індексу ліквідності та ін.

Звіт про рентабельність пропонуємо складати за прикладом таблиці 2. На основі його даних апарату управління підприємством 
Таблиця 2

Форма управлінського звіту про рентабельність підприємства

\begin{tabular}{|c|c|c|c|c|c|c|}
\hline № & Показник & $\begin{array}{c}\text { Формула розрахунку } \\
\text { (за даними фрінансової } \\
\text { звітності) }\end{array}$ & $\begin{array}{l}\text { Норматив. } \\
\text { значення }\end{array}$ & $\underset{1}{\text { Період }}$ & $\underset{2}{\text { Період }}$ & $\begin{array}{c}\text { Абсолютне } \\
\text { відхилення/ } \\
\text { Відносне } \\
\text { відхилення }\end{array}$ \\
\hline 1 & $\begin{array}{l}\text { Рентабельність } \\
\text { активів, \% }\end{array}$ & 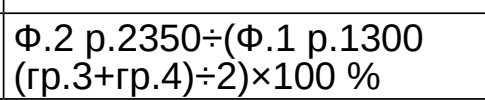 & $>14$ & & & \\
\hline 2 & $\begin{array}{l}\text { Рентабельність } \\
\text { власного } \\
\text { капіталу, \% }\end{array}$ & 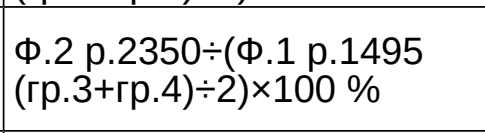 & $\geq 20$ & & & \\
\hline 3 & $\begin{array}{l}\text { Рентабельність } \\
\text { продажів, \% }\end{array}$ & Ф.2 p. $2350 \div$ p. $2000 \times 100 \%$ & $>30$ & & & \\
\hline
\end{tabular}

Джерело: сорормовано авторами

необхідно відслідковувати зміни розрахункових показників у досліджуваних періодах, а при значному їх відхиленні визначати срактори, що вплинули на це та безпосередньо ступінь їх впливу (фракторний аналіз), щоб коригувати діяльність надалі. Крім показників, наведених у таблиці 2, для інтересів керівництва може бути доцільним розрахунок рентабельності діяльності, продукції тощо.

Існує багато методик розрахунку ймовірності настання банкрутства підприємства. Вважаємо, однією 3 найоптимальніших $€$ модель Е. Альтмана:

$$
Z=1,2 X_{1}+1,4 X_{2}+3,3 X_{3}+0,6 X_{4}+X_{5}
$$

де $X_{1}-$ робочий капітал/усього активів;

$X_{2}-$ нерозподілений прибуток/усього активів;

$X_{3}$ - прибуток до оподаткування/усього активів;

$X_{4}$ - власний капітал/зобов'язання;

$X_{5}-$ чистий дохід/усього активів.

Рекомендуємо формувати звіт про потенційність банкрутства на її основі (табл. 3).

Результати звіту потрібно інтерпретувати залежно від значення розрахованого Z-коефіцієнта: $\leq 1,8$ - дуже висока ймовірність банкрутства, 1,81-2,67 - середня, 2,68-2,99 низька, $\geq 3,0$ - дуже низька. Відповідно, чим вища потенційність банкрутства, тим нижчий рівень фрінансового потенціалу підприємства.

Висновки. Отже, метою управлінської звітності являється забезпечення менеджерів на всіх рівнях управління достовірною, оперативною та корисною інформацією для поточного і стратегічного управління діяльністю підприємства. Види та структура управлінської звітності залежатимуть від рівня управління. Єдиних фрорм звітів, які б задовольняли потреби всіх установ і організацій, не існує; оптимально вони поділяються на ті, що стосуються фрінансового стану та результатів діяльності, ключових показників роботи, виконання різноманітних бюджетів. На наш погляд, кожне підприємство, будучи зацікавленим у власній фрінансовій стабільності, повинне фрормувати управлінські звіти, що відображатимуть основні показники його ліквідності, платоспроможності, рентабельності, ймовірності банкрутства. Для цього пропонуємо використовувати представлені в дослідженні фрорми звітів, доповнювати їх залежно від особливостей діяльності суб'єкта

Форма управлінського звіту про потенційність банкрутства підприємства

Таблиця 3

(за методикою Е. Альтмана)

\begin{tabular}{|c|c|c|c|c|c|}
\hline № & Коефріцієнт & $\begin{array}{c}\text { Формула розрахунку (за даними } \\
\text { фрінансової звітності) }\end{array}$ & $\begin{array}{c}\text { Період } \\
1\end{array}$ & $\begin{array}{c}\text { Період } \\
2\end{array}$ & $\begin{array}{l}\text { Абсолютне } \\
\text { відхилення }\end{array}$ \\
\hline 1 & $X_{1}$ & 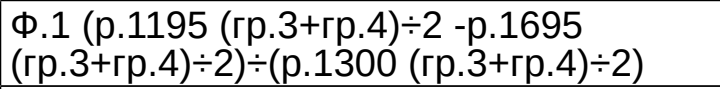 & & & \\
\hline 2 & $\mathrm{X}_{2}$ & 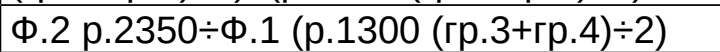 & & & \\
\hline 3 & $X_{3}$ & 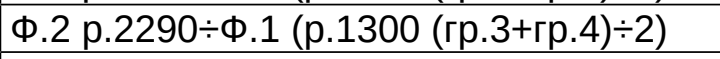 & & & \\
\hline 4 & $\mathrm{X}_{4}$ & 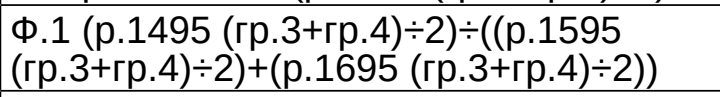 & & & \\
\hline 5 & $X_{5}$ & 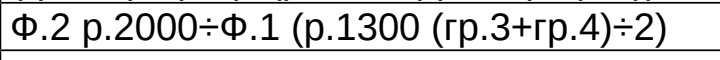 & & & \\
\hline 6 & Z & $1,2 \times 1+1,4 \times 2+3,3 \times 3+0,6 \times 4+X 5$ & & & \\
\hline
\end{tabular}


господарювання, потреб керівництва тощо. щодо періодичності складання даних фоорм, вважаємо оптимальним формувати звіти як за результатами звітного року, так і в розрізі кварталів.
Перспективою подальших досліджень буде розробка фрорм управлінської звітності для загального аналізу та оцінки фрінансової стійкості та ділової активності вітчизняних комерційних підприємств.

\section{СПИСОК ВИКОРИСТАНИХ ДЖЕРЕЛ:}

1. Куцик П.О. Сучасне трактування, склад і особливості фрормування управлінської звітності підприємства. Вісник Національного університету «Львівська політехніка». Менеджмент та підприємництво в Україні: етапи становлення і проблеми розвитку. 2014. № 797. С. 248-254.

2. Король С.Я. Управлінська звітність: сутність іалгоритм фрормування. Бізнес/нфрорм. 2014. № 7. С. 325-330.

3. Кузь В.І., Кравчук В.С. Управлінська бухгалтерська звітність підприємства: принципи та підходи до формування. Вісник Чернівецького торговельно-економічного інституту. Економічні науки. 2015. Вип. 2. С. 188-197.

4. Гладій І.О. Управлінська звітність підприємства: принципи формування. Глобальні та національні проблеми економіки. 2018. Вип. 23. С. 604-609.

5. Про бухгалтерський облік та фрінансову звітність в Україні : Закон України від 16.07.1999 № 996-XIV. Дата оновлення: 01.07.2021. URL: https://zakon.rada.gov.ua/laws/show/996-14 (дата звернення: 21.10.2021).

6. Шепель Т.П. Роль і місце управлінської звітності в підвищенні ефрективності функціонування підприємств. Інвестиції: практика та досвід. 2018. № 16. С. 31-34.

7. Галицький О.М. Роль і місце управлінського обліку в підвищенні ефрективності використання матеріально-технічної бази сільськогосподарських підприємств. Економіка та держава. 2014. № 1. С. 36-39.

8. Лучко М.Р., Жукевич С.М., Фаріон А.І. Фінансовий аналіз : навчальний посібник. Тернопіль : ТНЕУ, 2016. 304 с.

9. Скрипник М.І., Григоревська О.О., Вигівська І.М. Формати бухгалтерської управлінської звітності: методика визначення і формування. Глобальні та національні проблеми економіки. 2017. Вип. 18. С. 568-573.

\section{REFERENCES:}

1. Kutsik P.O. (2014) Suchasne traktuvannya, sklad i osoblivosti formuvannya upravlinskoi znitnosti pidpriemstva [Modern Interpretation, Composition and Features of the formation of management reporting of the enterprise]. Visnik Natsionalnogo universitetu «Lvivska politehnika». Management and Entrepreneurship in Ukraine: Stages of Formation and Problems of Development, 797, 248-254. (in Ukrainian)

2. Korol S.Y. (2014) Upravlinska zvitnist: sutnist I algoritm formuvannya [Management reporting: the essence and algorithm of formation]. BussinesInform, 7, 325-330. (in Ukrainian)

3. Kuz V.I., Kravchuk V.S. (2015) Management accounting: principles and approaches to formation [Management accounting: principles and approaches to formation]. Bulletin of the Chernivtsi Trade and Economic Institute, 58, 188-197. (in Ukrainian)

4. Hladii I.O. (2018) Upravlinska zvitnist pidpryiemstva: pryntsypy formuvannia [Management accounting of an enterprise: principles of formation]. Hlobalni ta natsionalni problemy ekonomiky, 23, 604-609. (in Ukrainian)

5. Pro bukhhalterskyi oblik ta finansovu zvitnist v Ukraini: Zakon Ukrainy vid 16.07.1999 № 996-XIV. Data onovlennia: 01.07.2021. Retrieved from: https://zakon.rada.gov.ua/laws/show/996-14 (accessed: 21 October 2021).

6. Shepel T.P. (2018) Rol i mistse upravlinskoi zvitnosti v pidvyshchenni efektyvnosti funktsionuvannia pidpryiemstv [The Role and Place of Managerial Reporting in Improving the Efficiency of Enterprises]. Investments: practice and experience, 16, 31-34. (in Ukrainian)

7. Halytskyi O.M. (2014) Rol i mistse upravlinskoho obliku v pidvyshchenni efektyvnosti vykorystannia materialno-tekhnichnoi bazy silskohospodarskykh pidpryiemstv [The role and Place of Management Accounting in Improving the Efficiency of the Material and Technical Base of Agricultural Enterprises]. Ekonomika ta derzhava, 1, 36-39. (in Ukrainian)

8. Luchko M.R., Zhukevych S.M., Farion A.I. (2016) Finansovyi analiz: navchalnyi posibnyk. Ternopil: TNEU, 304 p. (in Ukrainian)

9. Skrypnyk M.I., Hryhorevska O.O., Vyhivska I.M. (2017) Formaty bukhhalterskoi upravlinskoi zvitnosti: metodyka vyznachennia i formuvannia [Formats of Accounting Management Reporting: Methods of Definition and Formation]. Hlobalni ta natsionalni problemy ekonomiky, 18, 568-573. (in Ukrainian) 